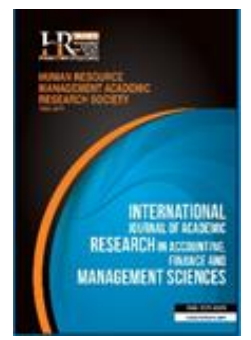

International Journal of Academic Research in Accounting, Finance and Management Sciences

Vol. 8, No.2, April 2018, pp. 164-169

E-ISSN: 2225-8329, P-ISSN: 2308-0337

(C) 2018 HRMARS

www.hrmars.com

To cite this article: Tepus, A.-M. (2018). The Relationship between the Capital Market and the Real Economy. The Case of the European Union, International Journal of Academic Research in Accounting, Finance and Management Sciences 8 (2): 164-169.

\title{
The Relationship between the Capital Market and the Real Economy: The Case of the European Union
}

\author{
Ana-Maria TEPUS \\ The Bucharest Academy of Economic Studies, Romania, E-mail: actincon@yahoo.com
}

\begin{abstract}
In this paper we investigate the existence of a correlation between the capital market and the real economy in the case of the European Union using panel type data. Estimates of the panel model for the European Union have shown that the relationship is bidirectional, stronger from the real economy toward the capital market, with noticeable differences between countries.

Key words Capital market, economic growth, panel data

Received: 25 May 2018 (c) The Authors 2018

Revised: 16 Jun 2018 Published by Human Resource Management Academic Research Society (www.hrmars.com)

Accepted: 28 Jun 2018 This article is published under the Creative Commons Attribution (CC BY 4.0) license. Anyone may Published Online: $04 \mathrm{Jul} 2018$ reproduce, distribute, translate and create derivative works of this article (for both commercial and noncommercial purposes), subject to full attribution to the original publication and authors. The full terms of this license may be seen at: http://creativecommons.org/licences/by/4.0/legalcode
\end{abstract}

\section{Introduction}

Specialist literature abounds in works that uniquely and bidirectionally investigate the link between the degree of development of the capital market and the rhythm of growth of the real economy. Thus, Obreja-Braşoveanu et al. (2008), in a study analyzing the link between the capital market and economic growth in Romania during 2000-2006, concludes that there is a significant correlation between the two elements, with a feed-back effect, but a stronger causality is evident from the economic growth towards the capital market, which suggests that in the case of Romania the economic growth is a factor that determines the development of financial institutions.Also, Shahbaz and Ali (2008), estimating ARDL ${ }^{1}$ type models and carrying out a Granger causality analysis for the Pakistani economy, concluded that there was a bi-directional positive relationship between economic growth and the development of the capital market. Ozbay (2009), analyzing the economy and the capital market in Turkey, reaches the same conclusion of bidirectional causality.

Liu and Kompaniyets (2015) have implemented dynamic models to capture as many as possible of the random factors both common, which represent the move between the real economy and the financial markets, as well as sectorial factors that embrace the intrinsic movements of the real economy and financial markets. These variations are explained by co-movements that show that the link index is extremely influenced by financial/creditor indicators, but stock indices appear to work together one with each other. However, much of the variation remains still inexplicable. Whereas at the level of the European Union, the 27 Member States show obvious heterogeneities in terms of the level of economic development, as well as in terms of the degree of improvement of the financial intermediation services,

\footnotetext{
${ }^{1}$ Auto Regressive Distributed Lag
} 
this paper intends to highlight the relationship between the capital market and the real economy, taking into account these specific differences between the EU countries.

At the same time, the European Union is working to implement two major economic initiatives: the Banking Union and the Capital Markets Union (CMU). The Banking Union aims to thorough banking markets integration, using for this purpose unique surveillance tools, a common resolution mechanism and a single framework for bank deposit guaranteeing.

CMU aims to create a single capital market for the Eurozone and brings with it a maximization of benefits, namely an efficient targeting of financial resources to all the neuralgic points within the EU. There is at present a sharp granularity of stock exchanges at the European level, where 5 stock institutions account for about $95 \%$ of the total capitalization. In this paper, reference is made to the effect that an increase in stock market volatility may have on the economy. With an increase in volatility with a standard deviation, a decline in GDP of EUR 4.63 million is registered, according to this analysis.

The 2008 economic crisis validated this analysis because an average GDP decrease of EUR 181 million existed. A remodeling of the capital market through the CMU could bring clear benefits, such as innovation, competitiveness, a substantial reduction in systemic risks and, last but not least, economic growth.

In this paper we investigate the existence of a correlation between the capital market and the real economy in the case of the European Union using panel type data. Estimates based on the panel model for the European Union have shown that the relationship is bidirectional, stronger from the real economy to the capital market, with noticeable differences between countries.

\section{Data and methodology of research}

In this paper we used the regression methodology for panel type data for economic and financial variables in the European Union during 2000-2017.

Table 1. List of variables used

\begin{tabular}{|c|c|c|c|c|}
\hline Variable & Source & Frequency & Transformations made & Measure Unit \\
\hline Budgetary deficit & Eurostat & quarterly & Deflation & $\%$ GDP \\
\hline Current account deficit & Eurostat & quarterly & - & $\%$ GDP \\
\hline Public debt & Eurostat & quarterly & Deflation & $\%$ GDP \\
\hline Earnings index for each country & Bloomberg & daily & quarter mean & point \\
\hline GDP & Eurostat & quarterly & $\begin{array}{c}\text { Deseasonalisation, } \\
\text { deflation }\end{array}$ & $\begin{array}{c}\text { mil. national } \\
\text { MU }\end{array}$ \\
\hline Unhappiness index & $\begin{array}{c}\text { Economist Intelligence } \\
\text { Unit }\end{array}$ & annual & quarter mean & point \\
\hline
\end{tabular}

To estimate the unidirectional link from the capital market towards the real economy, the following model was estimated:

$$
\begin{aligned}
\Delta G D P_{i t}=\alpha+ & \beta_{1} \Delta \text { Unhappiness index } x_{i t}+\beta_{2} \text { Budgetary deficit } \\
& +\beta_{3} \Delta \text { Current Account Deficit } t_{i t}+\beta_{4} \Delta \text { Public debt }_{i t}+\beta_{5} \theta_{t} \\
& +\sum_{i=1}^{27} \beta_{5+i} \text { Country yield } i+\varepsilon_{i t}
\end{aligned}
$$

Where: $i$ represent the country, $t$ represents the time period. $\vartheta_{t}$ is a dummy that captures the effect of the crisis, as follows:

$\theta_{t}=\left\{\begin{array}{l}0, \text { if } t<2008 T 3 \\ 1, \text { if } t \geq 2008 T 3\end{array}\right.$ 
The Country yield variable $i$ takes values only for the country $i$, with $i=1 \ldots 27$, and elsewhere is zero. Thus, the coefficient of this variable is interpreted as showing the contribution of the yield of each country's stock index on the GDP growth ${ }^{2}$ in that country. This can be interpreted as showing the intensity of the relationship between the capital market (measured by the return on the stock market index) and the real economy (measured by GDP growth). To estimate the unidirectional link from the real economy towards the capital market, the following model was used:

Yield $_{i t}=\alpha+\beta_{1}$ UUnhappiness index $x_{i t}+\beta_{2}$ Budgetary deficit

$$
\begin{aligned}
& +\beta_{3} \Delta \text { Current Account Deficit }{ }_{i t}+\beta_{4} \Delta \text { Public debt } t_{i t}+\beta_{5} \theta_{t} \\
& +\sum_{i=1}^{27} \beta_{5+i} \Delta \text { PIBCountry } y_{i}+\varepsilon_{i t}
\end{aligned}
$$

In the above equation $\triangle P I B C_{\text {Country }}$ and it is GDP interacted with a dummy for each country, so that this variable has stack values only for the country $i$.

\section{Empirical results}

Table 2 shows the results of the fixed effect estimate, and robust standard deviations are transcribed in brackets. The same convention is maintained to indicate significant variables at 5 and $10 \%$.

Table 2. Results of fixed-effect panel regression. The unilateral relationship from the capital market towards

\begin{tabular}{|c|c|c|c|}
\hline $\mathrm{R}^{2}$ in group & 0.2866 & & \\
\hline $\mathrm{R}^{2}$ among the groups & 0.0885 & & \\
\hline $\mathrm{R}^{2}$ per total & 0.2748 & & \\
\hline Dependent variable $\triangle P I B$ & Coefficient & Dependent variable $\triangle P I B$ & Coefficient \\
\hline \multirow{2}{*}{$\Delta($ Unhappiness index $)$} & -0.0084 & \multirow{2}{*}{ Lithuania } & 0.0292 \\
\hline & $(0.0009)^{* *}$ & & $(0.0073)^{* *}$ \\
\hline \multirow{2}{*}{ Budgetary deficit } & 0.0006 & \multirow{2}{*}{ Luxembourg } & 0.0618 \\
\hline & $(0.0003)^{* *}$ & & $(0.0021)^{* *}$ \\
\hline \multirow{2}{*}{$\Delta$ (Public debt) } & -0.0007 & \multirow{2}{*}{ Malta } & 0.0275 \\
\hline & $(0.0004)^{*}$ & & $(0.0090)^{* *}$ \\
\hline \multirow{2}{*}{$\Delta$ (Current account deficit) } & -0.0022 & \multirow{2}{*}{ The Netherlands } & 0.0015 \\
\hline & $(0.0011)^{*}$ & & -0.0016 \\
\hline \multirow{2}{*}{ Dummycr } & -0.0066 & \multirow{2}{*}{ Poland } & 0.17 \\
\hline & $(0.0016)^{* *}$ & & $(0.0033)^{* *}$ \\
\hline \multirow{2}{*}{ Austria } & 0.0378 & \multirow{2}{*}{ Portugalia } & 0.0364 \\
\hline & $(0.0018)^{* *}$ & & $(0.0020)^{* *}$ \\
\hline \multirow{2}{*}{ Belgium } & 0.0331 & \multirow{2}{*}{ Romania } & 0.1041 \\
\hline & $(0.0019)^{* *}$ & & $(0.0032)^{* *}$ \\
\hline \multirow{2}{*}{ Bulgaria } & 0.0152 & \multirow{2}{*}{ Slovenia } & 0.0375 \\
\hline & $(0.0071)^{* *}$ & & $(0.0031)^{* *}$ \\
\hline \multirow{2}{*}{ Cyprus } & -0.0082 & \multirow{2}{*}{ Slovakia } & 0.0235 \\
\hline & $(0.0018)^{* *}$ & & $(0.0037)^{* *}$ \\
\hline \multirow{2}{*}{ Czech Republic } & 0.1131 & \multirow{2}{*}{ Spain } & -0.022 \\
\hline & $(0.0016)^{* *}$ & & $(0.0041)^{* *}$ \\
\hline \multirow{2}{*}{ Denmark } & 0.046 & \multirow{2}{*}{ Sweden } & 0.1712 \\
\hline & $(0.0029)^{* *}$ & & $(0.0015)^{* *}$ \\
\hline Estonia & 0.0692 & United Kingdom & 0.1316 \\
\hline
\end{tabular}
the real economy

${ }^{2}$ On GDP growth and not on the GDP level in that country because the natural logarithm of GDP was used in this section. 


\begin{tabular}{|c|c|c|c|}
\hline & $(0.0065)^{* *}$ & & $(0.0042)^{* *}$ \\
\hline \multirow{2}{*}{ Finland } & 0.0269 & \multirow{2}{*}{ Hungary } & 0.1533 \\
\hline & $(0.0013)^{* *}$ & & $(0.0034)^{* *}$ \\
\hline \multirow{2}{*}{ France } & 0.022 & \multirow{2}{*}{ Ireland } & 0.0276 \\
\hline & $(0.0015)^{* *}$ & & $(0.0025)^{* *}$ \\
\hline \multirow{2}{*}{ Germany } & 0.0413 & \multirow{2}{*}{ Italy } & 0.0158 \\
\hline & $(0.0019)^{* *}$ & & $(0.0016)^{* *}$ \\
\hline \multirow{2}{*}{ Greece } & 0.0153 & \multirow{2}{*}{ Latvia } & -0.0208 \\
\hline & $(0.0019)^{* *}$ & & -0.0225 \\
\hline \multirow{2}{*}{\multicolumn{2}{|c|}{ Source: Own calculations }} & \multirow{2}{*}{ Constanta } & 0.0152 \\
\hline & & & $(0.0008)^{* *}$ \\
\hline
\end{tabular}

Overall, at a European level, the capital market influences about $27 \%$ of the GDP variation and the $28 \%$ at the country level, as shown by the $\mathrm{R}^{2}$ statistic in the group.

The unhappiness index, public debt and current account deficit have a negative impact on GDP growth and only the budget deficit seems to have a positive effect. By analyzing the magnitude of the coefficients, it can be observed that the reduction of the unhappiness index by one unit determines an increase of the GDP by $0.84 \%^{3}$. The increase in the budget deficit has a positive impact of only $0.06 \%$ on GDP growth and the public debt of $0.07 \%$. Current account deficit decreases GDP by an average of $0.22 \%$. GDP has fallen due to the crisis by only $0.66 \%$ on average, ceteris paribus.

The panel type regression allows for the identification of each country's deviations from the average of the impact of the yield on real GDP at the level of the European Union. On average, the deviation is 5\% (coefficient 0.05 ). Countries can be grouped according to the intensity of the relation between the stock exchange index yield and the increase of GDP depending on the coefficient obtained in the regression.

Thus, it was considered an index that shows the impact of the increase in the yield with a percentage point on real GDP. If it causes an increase of less than $3 \%$ ceteris paribus, the link is weak; if the impact is between 3 and $5 \%$, the link is of medium intensity, and if it is greater than $5 \%$ the link is strong.

Table 3 shows the U.E. countries grouped according to the intensity of the relationship between the capital market and the real economy, as shown by the panel type regression presented above

Table 3. Influence of stock exchange index yield on real GDP growth

\begin{tabular}{|c|c|c|c|c|c|}
\hline \multicolumn{2}{|c|}{ Weak link } & \multicolumn{2}{|c|}{ Middle link } & \multicolumn{2}{|c|}{ Strong link } \\
\hline Country & Impact & Country & Impact & Country & Impact \\
\hline Spain & $-2.20 \%$ & Belgium & $3.31 \%$ & Luxembourg & $6.18 \%$ \\
\hline Latvia & $-2.08 \%$ & Portugal & $3.64 \%$ & Estonia & $6.92 \%$ \\
\hline Cyprus & $-0.82 \%$ & Slovenia & $3.75 \%$ & Romania & $10.41 \%$ \\
\hline The Netherlands & $0.15 \%$ & Austria & $3.78 \%$ & Czech Republic & $11.31 \%$ \\
\hline Bulgaria & $1.52 \%$ & Germany & $4.13 \%$ & United Kingdom & $13.16 \%$ \\
\hline Greece & $1.53 \%$ & Denmark & $4.60 \%$ & Hungary & $15.33 \%$ \\
\hline Italy & $1.58 \%$ & & & Poland & $17.00 \%$ \\
\hline France & $2.20 \%$ & & & Sweden & $17.12 \%$ \\
\hline Slovakia & $2.35 \%$ & & & & \\
\hline Finland & $2.69 \%$ & & & & \\
\hline Malta & $2.75 \%$ & & & & \\
\hline Ireland & $2.76 \%$ & & & & \\
\hline Lithuania & $2.92 \%$ & & & & \\
\hline
\end{tabular}

Source: Our own calculations following panel type regression

Table 4 shows randomized panel type regression results using the same conventions. The standard deviation is also robust.

${ }^{3}$ Because the dependent variable is logarithm and the regressions are in the level, the coefficients should be multiplied by 100 for a correct interpretation. 
Table 4. Random panel type regression results. The unilateral relationship from the real economy toward the capital market

\begin{tabular}{|c|c|c|c|}
\hline$R^{2}$ in group & 0.1231 & & \\
\hline$R^{2}$ intre groups & 0.2002 & & \\
\hline $\mathrm{R}^{2}$ per total & 0.1246 & & \\
\hline Dependent variable RT & Coefficient & Dependent variable $R T$ & Coefficient \\
\hline \multirow{2}{*}{$\Delta($ Inhappiness index $)$} & 0.002 & \multirow{2}{*}{ Lithuania } & 0.83 \\
\hline & -0.00527 & & $(0.080322)^{* *}$ \\
\hline \multirow{2}{*}{ Budgetary deficit } & -0.003 & \multirow{2}{*}{ Finlanda } & 0.93 \\
\hline & $(0.001266)^{* *}$ & & $(0.148583)^{* *}$ \\
\hline \multirow{2}{*}{$\Delta$ (Public debt) } & -0.004 & \multirow{2}{*}{ Portugal } & 1.34 \\
\hline & $(0.000998)^{* *}$ & & $(0.094553)^{* *}$ \\
\hline \multirow{2}{*}{$\Delta$ (Current account deficit) } & -0.01 & \multirow{2}{*}{ Luxembourg } & 0.84 \\
\hline & $(0.00254)^{* *}$ & & $(0.294575)^{* *}$ \\
\hline \multirow{2}{*}{ Crisis effect } & -0.04 & \multirow{2}{*}{ Belgium } & -0.58 \\
\hline & $(0.011079)^{* *}$ & & $(0.246854)^{* *}$ \\
\hline \multirow{2}{*}{ The Netherland } & 3.22 & \multirow{2}{*}{ Czech Republic } & 0.93 \\
\hline & $(0.120621)^{* *}$ & & $(0.041279)^{* *}$ \\
\hline \multirow{2}{*}{ Spain } & 1.39 & \multirow{2}{*}{ Estonia } & 1.34 \\
\hline & $(0.176103)^{* *}$ & & $(0.171938)^{* *}$ \\
\hline \multirow{2}{*}{ Greece } & 1.59 & \multirow{2}{*}{ Sweden } & 0.89 \\
\hline & $(0.126774)^{* *}$ & & $(0.077127)^{* *}$ \\
\hline \multirow{2}{*}{ Slovakia } & 0.66 & \multirow{2}{*}{ Slovenia } & 1.58 \\
\hline & $(0.345896)^{* *}$ & & $(0.2128)^{* *}$ \\
\hline \multirow{2}{*}{ Great Britain } & 1.47 & \multirow{2}{*}{ Bulgaria } & 0.44 \\
\hline & $(0.113057)^{* *}$ & & $(0.11467)^{* *}$ \\
\hline \multirow{2}{*}{ Italy } & 2.02 & \multirow{2}{*}{ Germany } & 0.13 \\
\hline & $(0.116092)^{* *}$ & & -0.39095 \\
\hline \multirow{2}{*}{ Cyprus } & 1.51 & \multirow{2}{*}{ Denmark } & 1.54 \\
\hline & $(0.117714)^{* *}$ & & $(0.048314)^{* *}$ \\
\hline \multirow{2}{*}{ Irlanda } & 0.95 & \multirow{2}{*}{ Austria } & 0.46 \\
\hline & $(0.167622)^{* *}$ & & $(0.03622)^{* *}$ \\
\hline \multirow{2}{*}{ Ungaria } & 0.92 & \multirow{2}{*}{ Romania } & 0.78 \\
\hline & $(0.390864)^{* *}$ & & $(0.079486)^{* *}$ \\
\hline \multirow{2}{*}{ Latvia } & 1.82 & France & 0.73 \\
\hline & $(0.126079)^{* *}$ & miance & $(0.075776)^{* *}$ \\
\hline Malta & 0.26 & Poland & 0.59 \\
\hline Trita & -0.23485 & 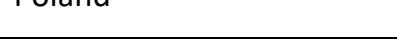 & $(0.277476)^{* *}$ \\
\hline Source: Own calculations & & Constanta & $\begin{array}{r}0 \\
-0.00671\end{array}$ \\
\hline
\end{tabular}

In contrast to the reverse relationship, it can be observed that the influence of the real economy on the yield, although significant, is lower than that of the yield on real economy; now $R^{2}$ has dropped to $12 \%$ both in total and in groups. However, the overwhelming majority of the coefficients remain significant even at $5 \%$, including the coefficients that show the contribution of GDP to the relevant country's stock exchange yield. The Unhappiness Index appears to be not significant at a level of $90 \%$. The budget deficit and government debt have roughly the same negative effect on the growth of stock exchange yields, resulting in a fall of $0.3 \%$ and $0.4 \%$ respectively in yields when they increase by one percentage point. The crisis has diminished ceteris paribus the European yields by $4 \%$ on average.

As in the previous case, it is possible to break down the impact of each country's GDP on the yield, dividing them by categories as follows: if the impact is less than $100 \%$, the link is considered poor (compared to the performance of the other countries), if the coefficient is less than $200 \%$, the link is considered to be meddium, and if it exceeds this threshold, the link is considered strong. Table 15 presents these results. 
Table 5. Influence of GDP growth on stock exchange index yield

\begin{tabular}{|c|c|c|c|c|c|}
\hline \multicolumn{2}{|c|}{ Weak link } & \multicolumn{2}{|c|}{ Middle link } & \multicolumn{2}{|c|}{ Strong link } \\
\hline Country & Impact & Country & Impact & Country & Impact \\
\hline Belgium & $-57.69 \%$ & Estonia & $134.11 \%$ & Italy & $201.84 \%$ \\
\hline Germany & $12.69 \%$ & Portugal & $134.49 \%$ & The Netherland & $321.60 \%$ \\
\hline Malta & $26.38 \%$ & Spain & $139.12 \%$ & & \\
\hline Bulgaria & $43.67 \%$ & Great Britain & $146.72 \%$ & & \\
\hline Austria & $46.13 \%$ & Cyprus & $150.67 \%$ & & \\
\hline Poland & $58.72 \%$ & Denmark & $153.53 \%$ & & \\
\hline Slovakia & $66.20 \%$ & Slovenia & $158.34 \%$ & & \\
\hline France & $73.44 \%$ & Greece & $158.58 \%$ & & \\
\hline Romania & $77.92 \%$ & Latvia & $182.37 \%$ & & \\
\hline Lithuania & $83.29 \%$ & & & & \\
\hline Luxembourg & $84.35 \%$ & & & & \\
\hline Sweden & $89.09 \%$ & & & & \\
\hline Hungary & $92.06 \%$ & & & & \\
\hline Czech Republic & $93.20 \%$ & & & & \\
\hline Finland & $93.49 \%$ & & & & \\
\hline Ireland & $94.91 \%$ & & & & \\
\hline
\end{tabular}

Source: Own calculations following panel regression

By comparison with the previously analyzed relationship, the following paradox is observed: although the real economy explains better the yield variation than the real economy explains the yield (as evidenced by the $R^{2}$ difference between the two regressions) the magnitude of the identified coefficients shows that the influence of the GDP on the stock exchange yields is much higher than the influence of the yields on GDP (highlighted by the individual coefficients of the countries in the two regressions.)

\section{Conclusions}

The panel type estimate models also confirm a stronger impact from the real economy toward the capital market: at the level of the whole Union, stock-exchange yield account for $28 \%$ of GDP, while GDP only accounts for $12 \%$ of the stock exchange yield fluctuation. Panel type regressions have highlighted the existence of a two-way relationship between the real economies towards the capital market. This relationship is stronger from the capital market towards the real economy. This may be due to the fact that stock exchanges have another function in addition to the one of redistributing the excessive capital: they are vulnerable to speculation, so that the real economy will never be able to explain $100 \%$ of the evolution of a stock exchange.

\section{References}

1. Liu, J., Kompaniyets, L., (2015). Co-Movements between Financial Markets and the Real Economy, working paper 003.

2. Obreja Brașoveanu, L., Dragotă, V., Cataramă, D., Semenescu, A. (2008). Correlations between Capital Market Development and Economic Growth: The Case of Romania, Journal of Applied Quantitative Methods, Vol. 3 (1), 2008, p. 64-75.

3. Ozbay, E. (2009). The relationship between stock returns and macroeconomic factors: evidence for Turkey, University of Exter, Disertation Paper.

4. Shahbaz, M., N., Ahmed, Ali, L. (2008). Stock market development and economic growth: ARDL causality in Pakistan, Int. Res. J. Fin. Econ., 14: p.182-195.

*** World Bank database

*** Bloomberg database

*** Eurostat database 